ARTICLE HISTORY: Received: January 18, 2021 Accepted: March 13, 2021 Published: March 19, 2021

\title{
DESIGNING A LOGISTICS NETWORK IN INTERNATIONAL TRADE
}

\author{
Barykin Sergey $E$. \\ Doctor of Economics, Associate Professor, \\ Professor of the Higher School of Service and Trade \\ of the Institute of Industrial Management of Economics and Trade (IPMEiT), \\ Wu Jing \\ Post-graduate student of the Department \\ of Logistics and Supply Chain Management, \\ St. Petersburg State University of Economics
}

\begin{abstract}
This article is devoted to the study of methods for solving the problem of increasing the economically sustainable development of international logistics networks, the study of the conditions of capital investments in logistics infrastructure with a positive accumulated cash balance as the accumulated amount of money flows with time stages of planning.

The methodology of T. L. Saati will allow you to combine all the important components (indicators for evaluating the company's performance: ROE, ROA, the ratio of own funds to attracted funds, etc.) into an analytical network.

Key words: stakeholders, partial functions, logistic integration, the combination of threads

\section{Introduction}

Against the background of the active position of competitors in the context of the projected slowing growth of international exchange of goods and services, it becomes relevant to identify effective ways to design logistics networks in international trade that serve as global value chains and a natural channel for the sale of manufactured goods and meeting the real demand for goods and products stimulated by integrated marketing communications. According to the author, a qualitative breakthrough in the implementation of the further development of the Russian economy cannot be achieved without the use of a new logistics methodology based on integrated design methods and models in combination with modern theories of the spatial organization of international logistics networks.
\end{abstract}

\section{Literary review}

According to the well-known scientist, the discoverer of world-system analysis, AND. A characteristic feature of the crisis of the modern globalized world order, which is another cyclical episode in the development of the world system, reflecting the change in the configuration of the world economy associated with the opening of borders and the free movement of goods and capital, is the increase in costs in proportion to the world's surplus value, including the development of infrastructure (which means roads, bridges and other public structures and structures considered as a system of production and trade) [2, p.242 - 248].

V. V. Tkach's scientific works are devoted to the study of transport and warehouse infrastructure as reference points for the configuration of flows of property rights to goods in the formed supply chain based on the structuring of supply contracts and the concept of contract strategy [17].

In the case of designing a logistics network, Professor T. G. Shulzhenko's approach to assessing the impact of logistics cost increases on return on assets (ROA) can be extended [8], taking into account the relationship between the return on assets with the total value of logistics costs and the cost of fixed assets [9].

Professor V. N. Naumov highlighted the prerequisites for strategic interaction in the sales system [11, p. 36-37], which can be extended to the general case of designing a logistics network.

In contrast to partial system analysis, in which only a certain part of the system is examined, logistics design covers the entire logistics system and involves determining the effectiveness of the mutual functioning of all its components [10, p. 625].

In [20], Professor V. V. Shcherbakov considered the application of the idea of adapting the theory and methods of decision-making to the problems of supply chain management. The tasks of supply chain management are interpreted in the context of the organization of paired interactions of participants and the formation of coalition structures. The effectiveness of the Bellman principle and the Pareto principle in making multi-step managerial decisions of a coordination orientation is shown.

A schematic diagram of a warehouse system with several levels of product promotion without a detailed consideration of the relationships in the network design models is considered by Professor Nerush [12], who highlighted the features of infrastructure formation. The influence of the elements of the logistics network in accordance with the causal relationship of the links in the supply chain and the phenomenon of interdependence in general is considered by Professor B. V. Korneychuk [6, p. 37], who defines interdependence in the aspect of improving the quality of life, which 
characterizes the status or social significance. However, the phenomenon of interdependence is not limited to the degree of impact, it is necessary to consider the interdependence of goals.

On the basis of general methodological approaches to the formation of logistics systems, it is possible to extend a number of general principles of scientific research of logistics networks in international trade [13, p. 182-188].

Formulated by Professor B. A. Anikin by the law of the constancy of the volume of material flow (on the immutability of physical volume of the elements of material flow in the supply chain from the manufacturer of commodity products through an intermediary to the consumer) [1, p. 40] can be considered a special case of the more General case in international logistics, which can be formulated as a commitment that the flow of customer value in the international logistics network, taking into account the interests of stakeholders.

In the process of developing a methodology for designing logistics networks in international trade, scientific publications can find arguments in favor of comparing the structure of a logistics cluster with the DNA model in relation to the design of a cross-border economic cluster [18, p.134]. Developing the idea of the analogy of the development of logistics interaction with the DNA helix, it is interesting to note the approach of comparing innovative development with the DNA helix. An international team of scientists consisting of Loet Leydesdorff, Yevgeny Perevodchikov and Alexander Uvarov analyzed the development of innovation infrastructure and identified insufficient integration of technologically advanced Russian firms [7] based on the methodology of the triple helix of innovation (government, industry, academic environment), developed by the Dutch scientist L. Leydesdorff [4, p.112].

The logistics process of international commodity exchange, regulated by the tools of customs administration, combines in principle the same elements, but related to the conduct of import and export deliveries. Professor E. A. Smirnova considered the typologization of supply chains due to trade and economic specifics, taking into account the complexity and ambiguity of approaches to supply chain management [16].

We can agree with Professor T. G. Shulzhenko of the fundamental importance to define the global logistics system research conceptual problems of correlation of the concepts of the global logistics system in the system of concepts of the theory of logistics, the classification of logistics systems, to identify features that distinguish the logistics system at the global scale from the national) [20, pp. $537-538]$.

The calculation of options for the development of the logistics network on an international scale should take into account the implementation of customs procedures considered by Professor A.V. Parfenov [15].

\section{Results}

On the analogy suggested by Professor A. O. Grudzinsky, "tetrahedron knowledge" [3] on top of which is an innovator in the logistics base of the tetrahedron is a "triangle of interaction of international resource flows of materials, finances and information", and on top of coordinating the interaction between flows and logistics provider (Fig. 1).

The spiral of interaction of flows of material, information and financial resources placed in a logistics tetrahedron is coordinated by an integrated logistics provider. The complexity of taking into account the conflicting interests of stakeholders can be reflected in the double prismatic model of correcting the integrity of the branch of the international supply chain (Cherenkov's double prismatic model of logistics management [19, p. 48]).

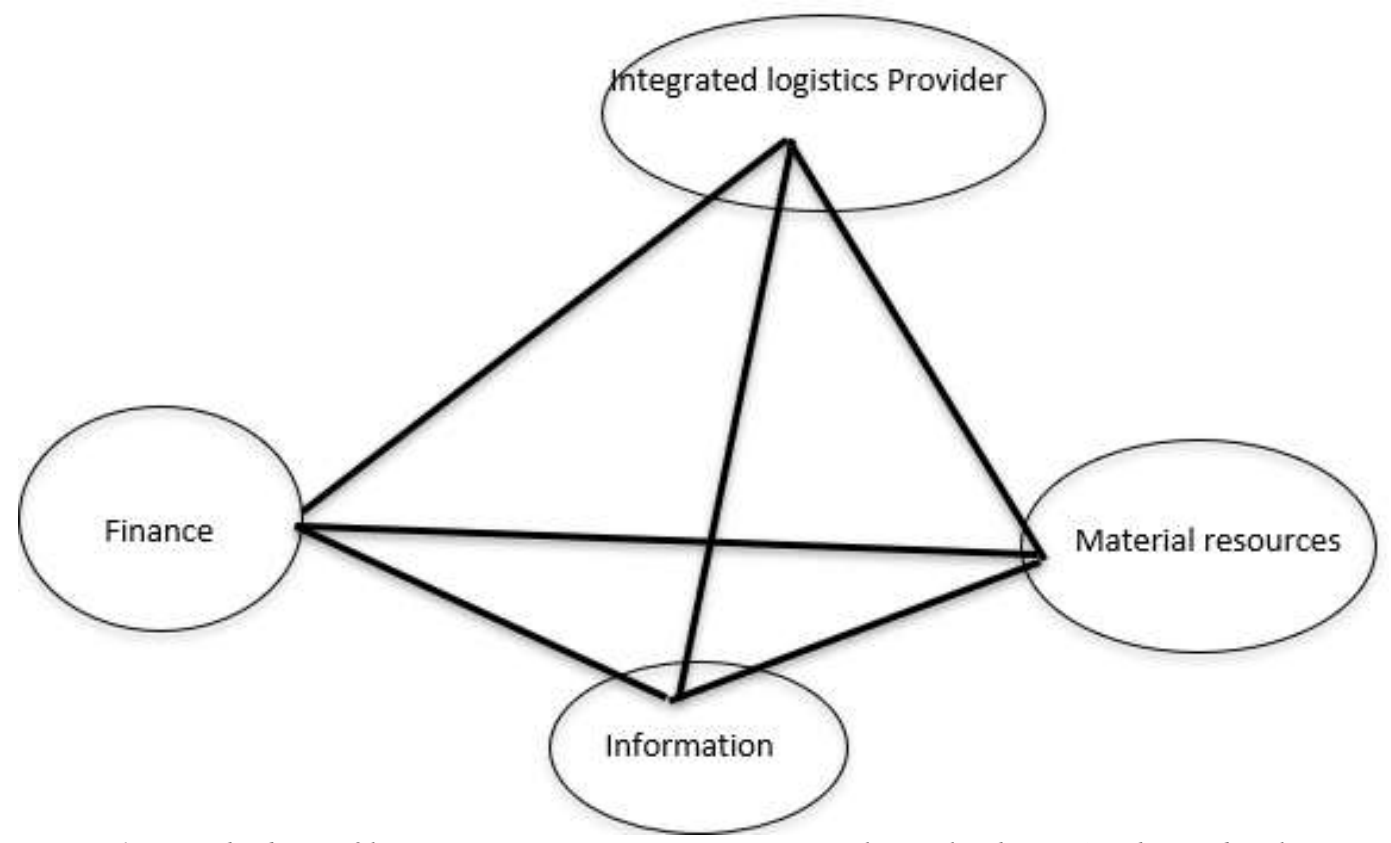

Figure 1. Tetrahedron of logistics integration in international supply chains (author's development) 
It is advisable to proceed from the assumption that logistics networks in international trade are formed in accordance with the global demands made by stakeholders to the entire supply chain of consumer value.

We can agree with Professor Naumov that the initial prerequisite for interaction (according to the author, not only in strategic, but also in tactical terms) is the coincidence of interests and the same idea of the functioning of the supply chain. Developing Naumov's assumption about the compatibility of corporate cultures and technological compatibility, it can be shown that the activity of the supply chain, as well as the level of interaction between the flows of material, information and financial resources, depends on the degree of compliance of the results of the design of the logistics network in international trade with the goals and interests of stakeholders.

In international supply chains, integration is achieved by streamlining the flow of information, financial resources, and materials. Such a complex scheme of forming an international logistics flow does not contradict the concept of representing the logistics flow as a set of information, material and financial resources. It can be shown that each channel under consideration (transactions, distribution and documentation) includes flows of information, financial and material resources, the partiality of which is characterized by the increased complexity of including financial resources mainly in the channel of transactions, material-in the channel of distribution and information resources - in the channel of documentation/communication (Fig. 2).

Described and illustrated as a system of three streams at the international level, developed by the author to introduce the idea of logistics integration in the form of a tetrahedron (Fig. 1) allows geometrically to reflect the property of parzialmente for example, integrated circuit formation integrated provider of international logistics flow aggregate information, material and financial resources (Fig. 2). Partiality is associated with the complexity of accounting for resources in the channel of transactions, distribution, and documentation (communication). Transaction, distribution, and documentation channels operate in an intertwined flow of information, financial, and material resources.

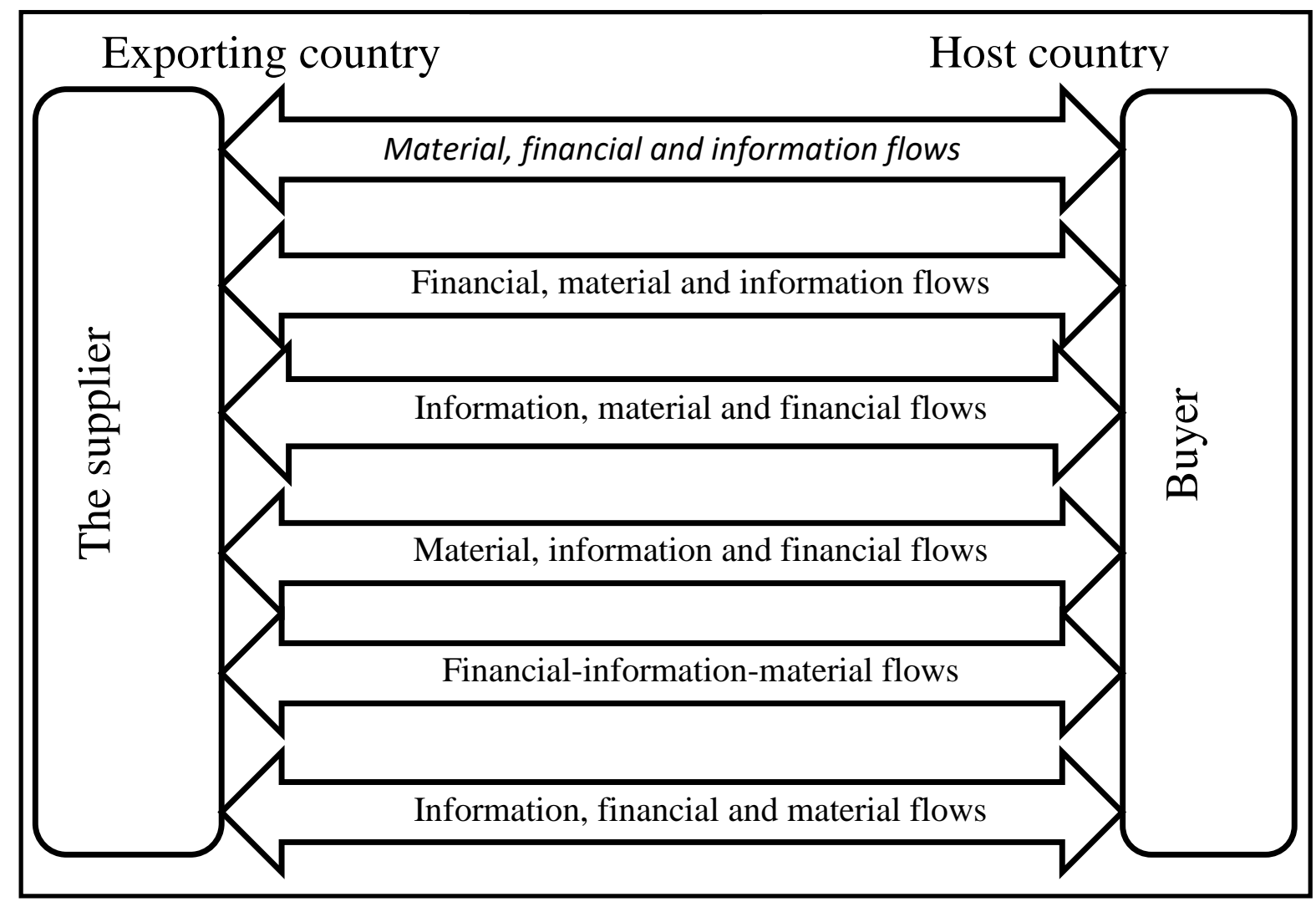

Figure 2. The combination of resource flows in the international logistics network in the channels of transactions, distribution and documentation (author's development)

International logistics the thread executing the partial function has a more complex structure compared to the logistic flow, combining information, material and financial resources, shared direction, integrated international logistics channel is characterized by the coordinated and non-separable structure [19, p. 62]:

- a channel of transactions where the purchase/sale (transfer of ownership) is legally implemented, provided by payment and related services (consulting, banking, legal); 
- distribution channel, through which the physical movement of goods is carried out, supported by the relevant services (packaging, loading and unloading, storage, transport);

- a documentation or communication channel (supported by information technology tools or services).

Coordination of the flows of material, information and financial resources may be considered in the context of creating a chain of consumer value taking into account the interests of the participants of the logistics network based on the author's proposed approach to building a harmonized supply chains for solar power, a concept outlined in relation to the problems of cooperation between flows of different types of resources from the perspective of stakeholder interests in the international circuit of creating consumer value in the process of delivery of components for solar in the following way (Fig. 3).

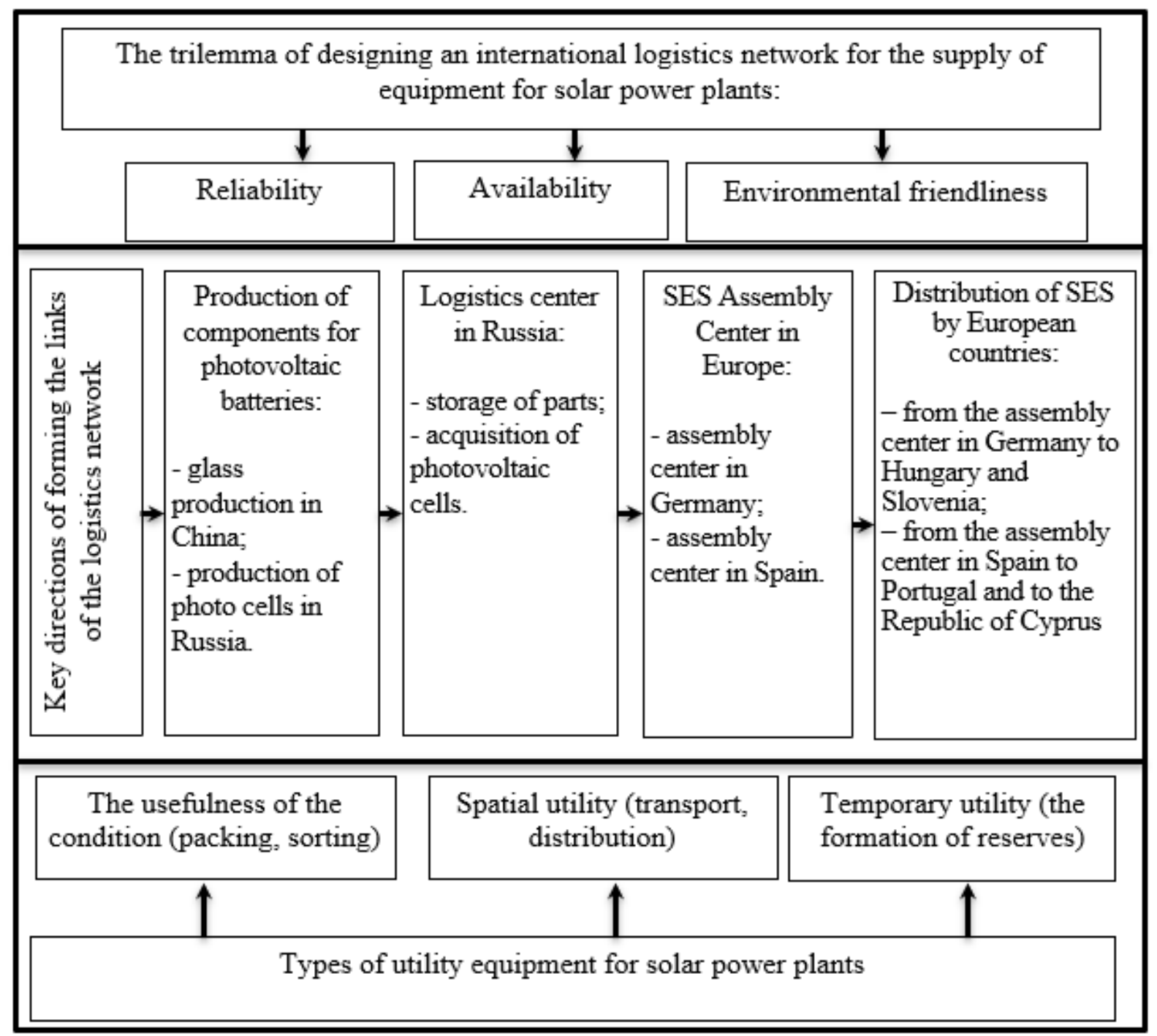

Figure 3. Map of the formation of the consumer value chain of power equipment for SES in accordance with the interests of stakeholders of the international logistics network (author's development)

\section{Discussion}

The formation of a logistics network in the international trade in electric power equipment should be carried out in accordance with the choice of an international strategy in the context of the speed of adaptation to the external environment of the international logistics chain and within the framework of the trilemma of energy development in Europe (energy security, reliability and energy efficiency).

It is advisable to proceed from the assumption that logistics networks in international trade are formed in accordance with the global demands made by stakeholders for the entire supply network of consumer value, including the energy supply system.

With respect to the supply of components for the Assembly of equipment solar power plants (SPP), we can formulate the condition of continuity as commitment to the continuity of the flow of customer value green energy best 
fit the interests of stakeholders in the implementation of the energy trilemma: security, affordability and sustainability of energy supply.

\section{Conclusion}

In general, the design of a logistics network covers the process of placing a logistics center in accordance with the methodology of network analysis, which allows us to develop methodological support for the placement of infrastructure objects, taking into account the conflicting interests of stakeholders.

The logistics network design methodology, which takes into account the degree of influence of the system elements in international trade, allows us to obtain estimates in a convenient form, taking into account the interests of stakeholders and the trilemma of energy development.

A comprehensive assessment, which showed the advantages of a logistics center with the possibility of completing equipment according to the main criteria, allows us to recommend the methodology for practical implementation in all major regions of the country.

\section{References}

[1] Anikin B. A., Tyapukhin A. P. Commercial logistics. - M.: Prospect, 2005.

[2] Wallerstein Immanuel World System Analysis: Introduction. . - ed. 2nd, ispr. ed. - M.: URSS: LENAND, 2018. $-304 \mathrm{p}$.

[3] Grudzinsky A. O., Bedny A. B. The concept of a competitive university: a tetrahedron model. 2012. no. 12. - p. 29-36.

[4] Itskovits G., Leidesdorf L. Dynamics of innovation: from national systems and "Regime 2 " to the Triple helix of university-industry-state relations // Research policy. - 2000. - No. 29. - pp. 109-123.

[5] Kapitonov E. A., Kapitonov A. E. Corporate culture. Monograph. - M.: JSC Rostizdat, 2001. - 384 p.

[6] Korneychuk B. V. Human capital in the time dimension. Transformational models of microeconomics. - St. Petersburg: "Severnaya Zvezda", 2004. - 196 p.

[7] Leidesdorf L., Perevodchikov E., Uvarov A. Measuring the synergy of the triple helix in Russian innovation systems at the regional, provincial and national levels. - 2015. - №6(66). - Pp. 1229-1238.

[8] Lukinsky V. V., Shulzhenko T. G. Integral assessment of logistics activity efficiency using key indicators // Logistics and supply chain management. - №6 (47). - 2011

[9] Lukinsky V. S., Shulzhenko T. G. Evaluation of the effectiveness of investments in logistics infrastructure based on the integral method of economic analysis. Logistika: sovremennye trendiy razvitiya: materialy XI Mezhdunar. Nauch.-pract. Conf. 2012 / ed. Kol.: V. S. Lukinsky. - St. Petersburg: SPBGIEU, 2012. - 472 p.

[10] Murphy, Paul R. Interaction management in the sales system: theory, methodology, strategies / Murphy, Paul R., Wood, Donald F. , - 8 ed. - M. : OOO "I. D. Williams", 2016.

[11] Naumov, V. N. Interaction management in sales and distribution: theory, methodology, strategy [Text] / - SPb. OOO "Polytechnic", 2011.

[12] Nerush, Y., gentry, C., Nerush, A. Designing logistics systems: tutorial and workshop / Y. Nerush, S. Panov, A. Nerush. - M.: Yurayt, 2015. 422 p.

[13] Odintsova T. N., Lukinsky V. S. Methodological principles of designing logistics systems of tourist services Logistics systems in the global economy. 2012. No. 2. pp. 182-188.

[14] Odintsova T. N., Lukinsky V. S. Methodological principles of designing logistics systems of tourist services Logistics systems in the global economy. 2012. No. 2. pp. 182-188.

[15] Parfenov A.V. Features of the application of customs logistics technologies within the single economic space [Text] / A.V. Parfenov, A. N. Morozov / / Logistics. - 2012. - No. 4. - p. 26-28.

[16] Smirnova E. A. Methodology of designing supply chains based on the principles of cross-border cooperation/ E. A. Smirnova// Bulletin of SUSU. Series: Economics and Management. - 2014. - No. 2. - pp. 168-174.

[17] Tkach V. V. On the question of the development of the concept of supply chain management / V. V. Tkach / / Logistics-Eurasian Bridge: materials of the VIII International Conference. scientific and practical conference Part 1. - Krasnoyarsk. - 2013. - 597 p.

[18] Freidman O. A. The process of designing a logistics cluster based on a problem-oriented approach and the method of analogies // Proceedings of the Volgograd State Technical University. - 2015. - №3(158). - P. 127-134.

[19] Cherenkov V. I. Osnovy mezhdunarodnoy logistiki: uchebno-metodicheskoe posobie [Fundamentals of international logistics: an educational and methodological manual]

[20] Shulzhenko T. G. Theoretical aspects of designing the structure of the global logistics system. In the collection: Modern management: problems and prospects Collection of articles: in two parts. - 2016. - p. 535-539.

Shcherbakov V. V., Saprykin I. G. Ideas of adaptation of the theory and methods of decision-making to the problems of supply chain management. 2010. No. 4. - pp. 215-216. 